\title{
Initial absolute growth dynamic of neem under supplemental irrigation with saline waters and biofertilizer
}

\section{Dinâmica do crescimento inicial absoluto de nim sob irrigação suplementar com águas salinas e biofertilizante}

\author{
Francisco de Oliveira Mesquita ${ }^{1 *}$; Rafael Oliveira Batista ${ }^{2}$; Lourival Ferreira \\ Cavalcante $^{3}$; Antônio Gustavo de Luna Souto ${ }^{4}$; Vinícius Batista Campos; \\ Francisco Roberto de Azevedo ${ }^{6}$; Adriana Araújo Diniz ${ }^{7}$; André Japiassú ${ }^{8}$
}

\begin{abstract}
The growing need to increase food production constitutes a serious scientific-technological challenge, requiring the expansion of cultivated sites also with the utilization of degraded areas, such as soils affected by salts. In order to achieve that, alternatives to mitigate such limitations have been pursued, such as the use of biofertilizers in the formation process of neem seedlings. In the pursuit for alternative and ecological control methods considered healthy and sustainable, the use of the neem tree (Azadirachta indica) associated with organic inputs in semiarid regions is highlighted, since this species possesses azadirachtin as the main bioactive compound, capable of acting against more than 418 plague species due to its insecticidal properties. An experiment was conducted in a screened plant nursery in the municipality of Areia - PB, in the period from January to July 2016, to evaluate the effects of the supplemental irrigation with saline waters on the absolute growth of neem seedlings in soil with biofertilizer. The substrate was a Dystrophic Red- Yellow Latosol. The experimental design was in randomized blocks, in a $5 \times 2 \times 3$ factorial scheme, with four replications. The treatments were irrigated with five levels of water salinity $\left(0.5 ; 1.5 ; 3.0 ; 4.5 ; 6.0 \mathrm{dS} \mathrm{m}^{-1}\right)$, in the soil without and with common fermented bovine biofertilizer, and evaluated after three periods: 30,60 , and 90 days after the emergence of the plantlets, for the determination of the absolute growth in AP, DC, IAF, MSR, MSPA, and MST. The liquid fermented biofertilizer, after diluted, was applied a single time in a 1:3 proportion, two days before sowing, at the level of $10 \%$ the volume of the substrate. The treatments with fermented bovine biofertilizer provided better conditions for the growth and development of the neem through osmotic effect than in the soil without the input as a function of the time.
\end{abstract}

Key words: Azadirachta indica. Biofertilization. Salt stress. Liquid bovine manure.

\footnotetext{
1 Pesquisador, Departamento de Recursos Hídricos, Instituto Nacional do Semiárido, INSA, Campina Grande, PB, Brasil. E-mail: mesquitaagro@yahoo.com.br

2 Prof., Departamento de Ciências Ambientais e Tecnológicas, Universidade Federal do Semi-Árido, UFERSA, Mossoró, RN, Brasil; E-mail: rafaelbatista@ufersa.edu.br

3 Prof., Departamento de Fitotecnia, Universidade Federal da Paraíba, UFPB, Areia, PB, Brasil. E-mail: lofeca1946@yahoo.com.br

4 Pós-Doutorado, Departamento de Agronomia, UFPB, Areia, PB, Brasil. E-mail: gusluso@hotmail.com

5 Prof., Departamento de Agronomia, Instituto Federal de Educação, Ciência e Tecnologia da Paraíba, IFPB, Princesa Izabel-PB, PB, Brasil. E-mail: vinicius.campos@ifpb.edu.br

6 Prof., Departamento de Entomologia, Universidade Federal do Cariri, UFCA, Juazeiro do Norte, UF, Brasil. E-mail: roberto. azevedo@ufca.edu.br

7 Prof ${ }^{a}$, Departamento de Agronomia, centro de Estudos Superiores de Balsas-CESBA, Universidade Estadual do Maranhão, UEMA, Balsas, MA, Brasil. E-mail: adrisolos@bol.com.br

8 Pesquisador, Dr. em Agronomia, Departamento de Fitotecnia, UFPB, Areia, PB, Brasil. E-mail: japiassuagro@gmail.com

* Author for correspondence
} 


\section{Resumo}

A crescente necessidade de se aumentar a produção de alimentos constitui um sério desafio científicotecnológico e tem requerido a expansão de áreas cultivadas, inclusive com o aproveitamento de áreas degradadas, como os solos afetados por sais. Para isso, tem-se buscado alternativas para mitigar tais limitações, como o uso de biofertilizantes no processo de formação das mudas de nim. Na busca por métodos de controle alternativo e ecológico, considerados saudáveis e sustentáveis, destaca-se a utilização do nim, Azadirachta indica, associado aos insumos orgânicos em regiões semiáridas por possuir azadiractina como principal composto bioativo, capaz de atuar contra mais de 418 espécies de pragas por suas propriedades inseticidas. Um experimento foi conduzido em abrigo telado no município de Areia - PB, no período de janeiro a julho de 2016, a fim de avaliar os efeitos da irrigação suplementar com águas salinas sobre o crescimento absoluto das mudas de nim no solo com biofertilizante. Como substrato foi utilizado um Latossolo Vermelho Amarelo distrófico. O delineamento experimental foi em blocos casualizados com esquema fatorial $5 \times 2 \times 3$, com quatro repetições. Os tratamentos foram irrigados com cinco níveis de salinidade de água $\left(0,5 ; 1,5 ; 3,0 ; 4,5 ; 6,0 \mathrm{dS} \mathrm{m}^{-1}\right)$, no solo sem e com biofertilizante bovino comum fermentado, avaliados após três períodos: 30, 60 e 90 dias após emergência das plântulas para determinação da taxa de crescimento absoluto em AP, DC, IAF, MSR, MSPA e MST. O biofertilizante liquido fermentado depois de diluído foi aplicado uma única vez na proporção de 1:3, dois dias antes da semeadura, ao nível de $10 \%$ do volume do substrato. Os tratamentos com biofertilizante bovino fermentado proporcionaram melhores condições ao crescimento e desenvolvimento do nim por efeito osmótico do que no solo sem o insumo em função tempo.

Palavras-chave: Azadirachta indica. Biofertilização. Stresse salino. Esterco bovino líquido.

\section{Introduction}

The neem (Azadirachta indica A. Juss) is an exotic tree of the Meliaceae family, being tolerant to water deficit and of rapid vegetative growth. It is also a widely studied plant due to its potential as a vegetal bioinsecticide in the control of agricultural plagues and animal parasites, besides contributing positively in the recuperation of physicallydegraded areas (DEBASHRI; TAMAL, 2012).

In the general production of good quality seedlings, efficient and, if possible, low-cost methodologies should be adopted (DUTRA et al., 2012; MESQUITA et al., 2019). Among the limitations for the cultivation of this species is the use of materials of high biological quality. In this phenological stage, and considering that the neem, during the first year, is moderately tolerant to salinity, growth inhibition might occur due to salinity or sodicity, as well as due to other limitations, such as water deficit in terms of quantity and quality (FREIRE et al., 2010; PEDROTTI et al., 2015; OLIVEIRA et al., 2017).
The physiological indexes involved and determined by the growth analysis indicate the ability of the assimilatory system of the plants in synthesizing and allocating organic matter in the several organs (drains) that rely on photosynthesis, respiration, and translocation of photoassimilates in the fixation sites (FONTES et al., 2005).

Growth reduction in some plants might be the result of a high saline level in the irrigation water, affecting the ionic balance, the nutritional composition, the hormonal balance, and the photosynthetic rate (MUNNS; TESTER, 2008; MESQUITA et al., 2015; OLIVEIRA et al., 2018).

The importance of the bovine biofertilizer on plant growth is not attached to the quantitative values of its chemical components, which are generally low, but rather to the qualitative values, due to their diversity (MESQUITA et al., 2012a; MEDEIROS et al., 2016; MESQUITA et al., 2019). Besides its chemical diversity, the biofertilizer stimulates the microbiological and enzymatic activity and promotes the release of nutrients and 
the physical improvement of the soil, resulting in higher plant growth and nutrition (MAVIA et al., 2012; NASCIMENTO et al., 2015). The application of the bovine fertilizer in the soil might induce the osmotic adjustment in the plants through the accumulation of organic solutes in the cells, as observed in the evaluations of the phenometric and productive components of the yellow passion fruit (Passiflora Edulis F. Flavicarpa Deg.) (FREIRE et al., 2010; MATSI et al., 2015).

The positive action of the bovine biofertilizer occurs in the edaphic improvement in terms of aeration, air and water dynamics (MELLEK et al., 2010; RIBEIRO et al., 2017), and in the possibility of humic substances from the organic matter to mitigate the depressive effects of water salinity in the plants (AYDIN et al., 2012). The employment of the respective organic input can inhibit the degenerative action of the salts and stimulate the initial growth of the plants during the formation of the seedlings (MESQUITA et al., 2012b, 2019).

In view of the foregoing, this work aimed to evaluate the effects of the irrigation water salinity on the absolute growth of Azadirachta indica in a soil with bovine biofertilizer.

\section{Material and Methods}

This research was conducted in a protected environment (plant nursery), in the period from January to July 2016, in the Department of Soils and Rural Engineering of the Center of Agrarian Sciences, Federal University of Paraíba (UFPB), located in the municipality of Areia, Paraíba state, Brazil, georeferrenced by the cartographic pointws $6^{\circ} 51^{\prime} 47^{\prime \prime}$ and $7^{\circ} 02^{\prime} 04^{\prime \prime}$ south latitude, $35^{\circ} 34^{\prime} 13^{\prime \prime}$ and $35^{\circ} 48^{\prime} 28^{\prime \prime}$ 'west longitude, with elevation of 575 $\mathrm{m}$ above sea level.

The climate of the region, according to the classification by Köppen, is As' (hot and humid), with average annual precipitation of $1,230 \mathrm{~mm}$, and rainy season in the period from March to July or until August (ALVARES et al., 2013). The average temperature of the region is $25.5^{\circ} \mathrm{C}$, mean relative air humidity of $71.7 \%$, with a maximum value of $85 \%$ in May and a minimum of $60 \%$ in January. In the hottest period of the experiment, the highest temperature in the interior of the plant nursery was registered in January, with a mean value of 47.7 ${ }^{\circ} \mathrm{C}$ and minimum of $33.5{ }^{\circ} \mathrm{C}$. In this same period, the mean relative air humidity varied from 44 to $57 \%$. These values were obtained through monthly readings in the dry and winter period.

The soil of the experimental area was characterized as a non-saline Dystrophic RedYellow Latosol of sandy texture (EMBRAPA, 2013), collected in the first $20 \mathrm{~cm}$ of depth. After the collection of the material, the samples were transported to the DSER/CCA/UFPB laboratory for grinding and drying. The soil samples, after passing through a $2 \mathrm{~mm}$ mesh sieve, were physically characterized as to their fertility by employing the methodologies compiled by EMBRAPA (2017). The samples were also characterized as to the salinity of the saturation extract according to Richards (1954), with results listed in Table 1. 
Table 1. Physical, chemical, and salinity characterization of the soil collected at the depth from $0-20 \mathrm{~cm}$ for the evaluation of the seedlings. Areia, PB, 2016.

\begin{tabular}{|c|c|c|c|c|c|}
\hline Fertility attributes & Value & Physical attributes & Value & Salinity attributes & Value \\
\hline $\mathrm{pH}$ in water $(1: 2,5)$ & 6.5 & $\mathrm{Sd}\left(\mathrm{g} \mathrm{cm}^{-3}\right)$ & 1.55 & CEes $\left(\mathrm{dS} \mathrm{m}^{-1}\right)$ & 0.71 \\
\hline $\mathrm{OM}\left(\mathrm{g} \mathrm{kg}^{-1}\right)$ & 12.2 & $\operatorname{Pd}\left(\mathrm{g} \mathrm{cm}^{-3}\right)$ & 2.57 & $\mathrm{pH}$ & 7.11 \\
\hline $\mathrm{P}\left(\mathrm{mg} \mathrm{dm} \mathrm{dm}^{-3}\right)$ & 28.6 & $\operatorname{Tp}\left(\mathrm{m}^{3} \mathrm{~m}^{-3}\right)$ & 0.47 & $\mathrm{Ca}^{2+}\left(\mathrm{mmol}_{\mathrm{c}} \mathrm{L}^{-1}\right)$ & 1.91 \\
\hline $\mathrm{K}^{+}\left(\mathrm{mg} \mathrm{dm}^{-3}\right)$ & 116 & Sand $\left(\mathrm{g} \mathrm{kg}^{-1}\right)$ & 864 & $\mathrm{Mg}^{2+}\left(\operatorname{mmol}_{\mathrm{c}} \mathrm{L}^{-1}\right)$ & 1.22 \\
\hline $\mathrm{Ca}^{+2}\left(\mathrm{cmol}_{\mathrm{c}} \mathrm{dm}^{-3}\right)$ & 1.5 & Silt $\left(\mathrm{g} \mathrm{kg}^{-1}\right)$ & 65 & $\mathrm{Na}^{+}\left(\mathrm{mmol}_{\mathrm{c}} \mathrm{L}^{-1}\right)$ & 3.32 \\
\hline $\mathrm{Mg}^{+2}\left(\mathrm{cmol}_{\mathrm{c}} \mathrm{dm}^{-3}\right)$ & 0.8 & Clay $\left(\mathrm{g} \mathrm{kg}^{-1}\right)$ & 88 & $\mathrm{~K}^{+}\left(\mathrm{mmol}_{\mathrm{c}} \mathrm{L}^{-1}\right)$ & 1.09 \\
\hline $\mathrm{Na}^{+}\left(\mathrm{cmol}_{\mathrm{c}} \mathrm{dm}^{-3}\right)$ & 0.3 & Ada $\left(\mathrm{g} \mathrm{kg}^{-1}\right)$ & 16 & $\mathrm{Cl}^{-}\left(\mathrm{mmol}_{\mathrm{c}} \mathrm{L}^{-1}\right)$ & 5.12 \\
\hline $\mathrm{H}^{+}+\mathrm{Al}^{+3}\left(\mathrm{cmol}_{\mathrm{c}} \mathrm{dm}^{-3}\right)$ & 1.1 & GF (\%) & 84.79 & $\mathrm{CO}_{3}^{2-}\left(\mathrm{mmol}_{\mathrm{c}} \mathrm{L}^{-1}\right)$ & - \\
\hline $\mathrm{Al}^{+3}\left(\mathrm{cmol}_{\mathrm{c}} \mathrm{dm}^{-3}\right)$ & 0.0 & DI (\%) & 15.44 & $\mathrm{HCO}_{3}^{-}\left(\mathrm{mmol}_{\mathrm{c}} \mathrm{L}^{-1}\right)$ & 1.42 \\
\hline $\mathrm{SB}\left(\mathrm{cmol}_{\mathrm{c}} \mathrm{dm}^{-3}\right)$ & 2.7 & $\mathrm{U}_{\mathrm{cc}}\left(\mathrm{g} \mathrm{kg}^{-1}\right)$ & 10.23 & $\mathrm{SO}_{4}{ }^{2-}\left(\mathrm{mmol}_{\mathrm{c}} \mathrm{L}^{-1}\right)$ & 0.99 \\
\hline $\operatorname{CEC}\left(\mathrm{cmol}_{\mathrm{c}} \mathrm{dm}^{-3}\right)$ & 4.2 & $\mathrm{U}_{\mathrm{pmp}}\left(\mathrm{g} \mathrm{kg}^{-1}\right)$ & 4.45 & $\operatorname{RAS}\left(\mathrm{mmol} \mathrm{L}^{-1}\right)^{1 / 2}$ & 2.67 \\
\hline V $(\%)$ & 69.9 & $\mathrm{Ad}\left(\mathrm{g} \mathrm{kg}^{-1}\right)$ & 5.66 & PST (\%) & 4.79 \\
\hline
\end{tabular}

$\mathrm{SB}=$ sum of bases $\left(\mathrm{Na}^{+}+\mathrm{K}^{+}+\mathrm{Ca}^{2+}+\mathrm{Mg}^{2+}\right) ; \mathrm{CEC}=$ Cation exchange capacity $=\mathrm{SB}+\left(\mathrm{H}^{+}+\mathrm{Al}^{3+}\right)$; $\mathrm{V}=$ Base saturation value $(100 \mathrm{xB} / \mathrm{CTC})$; PST=Percentage of exchangeable sodium $\left(100 \mathrm{xNa}^{+} / \mathrm{CTC}\right) ; \mathrm{Sd}=$ Soil density; $\mathrm{Pd}=$ Particle density; $\mathrm{Tp}=$ Total porosity; $\mathrm{DI}=$ Dispersion index; $\mathrm{SAR}=$ Sodium adsorption ratio $\mathrm{Na}^{+} \div\left[\left(\mathrm{Ca}^{2+}+\mathrm{Mg}^{2+}\right) / 2\right]^{1 / 2}$.

Plastic containers with a diameter of $26.1 \mathrm{~cm}$ of base, $37 \mathrm{~cm}$ of height, and a maximum capacity of $20 \mathrm{dm}^{-3}$ were used in the experiment. However, each experimental unit contained only $15 \mathrm{dm}^{-3}$ of the substrate. The base consisted of a $2 \mathrm{~cm}$ thick layer of coarse gravel $\left(n^{\circ} .20\right)$ and another layer of the same thickness of fine washed sand. Each experimental unit consisted of one neem plant per plastic container, following the seedling standardization system.

The adopted experimental design was in randomized blocks, with treatments distributed into four replications in a $5 \times 2 \times 3$ factorial scheme, referring to five levels of irrigation water salinity: $0.5 ; 1.5 ; 3.0 ; 4.5$, and $6.0 \mathrm{dS} \mathrm{m}^{-1}$, in the soil without and with liquid bovine biofertilizer, evaluated in the period of 60,120 , and 180 days after the emergence of the plantlets.

The irrigation was daily performed with a sufficient water volume to maintain the soil moisture close to field capacity, registering each volume applied. These irrigations were performed with non-saline $\left(\mathrm{CEa}=0.5 \mathrm{dS} \mathrm{m}^{-1}\right)$ and saline $(\mathrm{CEa}$
$=1.5 ; 3.0 ; 4.5 ; 6.0 \mathrm{dS} \mathrm{m}^{-1}$ ) water, and at every 15 days, soil washings were performed with each type of water employed in the irrigation of the plants.

The biofertilizer was obtained from a mixture of equal parts of fresh bovine manure and water (nonsaline and non-chlorinated) in a biodigester under anaerobic fermentation, during 30 days, according to Mesquita et al. (2012a). Two days before sowing, the biofertilizer was diluted in water in a 1:1 ratio and applied in a volume equivalent to $10 \%$ of the volume of the substrate $\left(15 \mathrm{dm}^{-3}\right)$. For the maintaining of the system, which was hermetically sealed, a $4 \mathrm{~mm}$ diameter hose was connected to the extremity of the pump, in the upper base of the biodigester, and the other extremity was immersed in a $2 \mathrm{~L}$ PET bottle containing water. Since the application occurs in liquid form, the biofertilizer was evaluated as if it were irrigation water, and it presented the following values: $\mathrm{Ca}^{2+}=1.16, \mathrm{Mg}^{2+}=0.69, \mathrm{Na}^{+}=2.47, \mathrm{~K}^{+}=0.18$, $\mathrm{Cl}^{-}=3.48 ; \quad \mathrm{HCO}_{3}=0.29, \quad \mathrm{SO}_{4}^{-2}=0.72 \quad \mathrm{mmol}_{\mathrm{c}} \mathrm{L}^{-1}$, electrical conductivity at $25{ }^{\circ} \mathrm{C}=3.41 \mathrm{dS} \mathrm{m}^{-1}$, and $\mathrm{pH}=6.72$ (RICHARDS, 1954). 
In each experimental unit, five seeds of Azadirachta indica A. Juss with $89 \%$ viability were sowed, as proceeded by Mesquita et al. (2019). The thinning of the plantlets was performed 30 days after the emergence, allowing only the most vigorous plantlet per vase. After sowing, monitoring was conducted to record the first count of normal plantlets emerged, and daily counts were performed until the end of the emergence to evaluate the biometric variables. In the period of 60,120 , and 180 days after the emergence of the plants, the plant height, stem diameter, leaf area index, and the shoot, root, and total dry matter were obtained in each experimental plot.

The plant height was determined with the aid of a millimeter rule; the stem diameter was determined with a digital pachymeter (Digimess ${ }^{\circledR}$ ); and the dry vegetal material (root+leaves) was obtained after drying in a forced air circulation oven at $65^{\circ}$ $\mathrm{C}$ until constant weight. The determination of the leaf area index was performed using the following formula: $\mathrm{IAF}=\mathrm{AF} / \mathrm{AS}$, where $\mathrm{AF}$ is the leaf area in $\mathrm{cm}^{2}$ and AS is the soil area under domain of the neem seedlings, in $\mathrm{cm}^{2}$, evaluated at the end of the experiment.

The growth of the seedlings was evaluated based on the data of plant height $(\mathrm{PH})$, stem diameter (SD), shoot dry matter (SDM), root dry matter (RDM), and total dry matter (TDM), obtaining the absolute growth dynamics of plant height (CAPH), stem diameter (CASD), shoot dry matter (CASDM), and total dry matter (CATDM) of the neem seedlings evaluated as a function of the time, respectively according to the bellow-described equations for each analyzed variable, studied in three distinct times: 60, 120, and 180 days after the emergence of the plantlets. The formulas used for the determination of the congruence of the absolute growth were in accordance with (MESQUITA et al., 2012b), TCA $=(\mathrm{V} 2-\mathrm{V} 1) /(\mathrm{T} 2-\mathrm{T} 1)$. In which, according to the formula, $\mathrm{V}$ means the variable and $\mathrm{T}$ is the time of each period, respectively.

The obtained data were subjected to analysis of variance by the " $F$ " test, and to polynomial regression for the salinity levels (BANZATTO; KRONKA, 2008). For data processing, a demonstrative version of the SISVAR $^{\circledR}$ software was employed (FERREIRA, 2011).

\section{Results and Discussion}

The onset of neem seedling emergence occurred five days after sowing, although the stabilization of the germinative process was only reached at 21 days after sowing, presenting a viability of $89 \%$, being an epigeal germination.

When evaluating the height of the neem seedlings through the analysis of absolute growth in the period of 60 (period 1), 120 (period 2), and 180 days (period 3) after the emergence of the plantlets, regardless of the organic input, the seedlings registered maximum values of $0.28 ; 0.38$, and $0.50 \mathrm{~cm}_{\text {day }}{ }^{-1}$, that is, corresponding to the estimated maximum electrical conductivity of the irrigation water of $2.85 ; 2.93$, and $2.35 \mathrm{dS} \mathrm{m}^{-1}$, considering that there was homogeneity in the vigor of Azadirachta indica as a function of each experimental time evaluated (Figure 1). In this perspective, it is verified that the neem plants, at the end of the experiment, increased their yields in up to $74.41 \%$ referring to the limit salinity of $2.83 \mathrm{dS} \mathrm{m}^{-1}$ on the absolute growth. The growth rate of the seedlings was $0,10 \mathrm{~cm} \cdot$ day $^{-1}$. 
Figure 1. Absolute growth (CA) in the height (AP) of the neem seedlings under supplemental irrigation with saline waters evaluated in the period of $60(--), 120(--)$, and $180(-)$ days after the emergence of the plantlets (DAE). CCA/UFPB, Areia-2016.

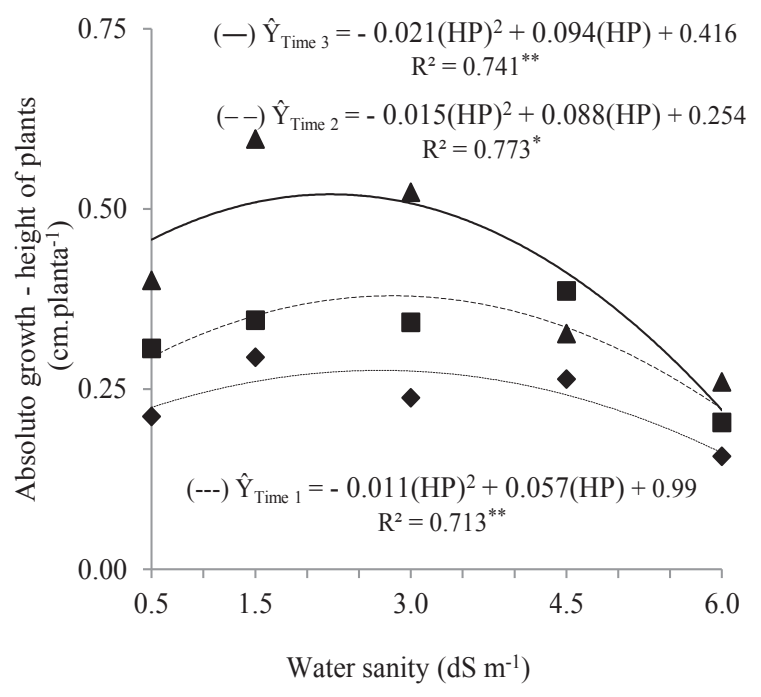

The behavior of these data is in accordance with Dantas et al. (2009) and Mesquita et al. (2012b) when confirming, in the cultivation of Poincianella pyramidalis at $100 \mathrm{DAE}$ and of yellow passion fruit at $60 \mathrm{DAE}$, satisfactory results in the rate of absolute growth in height of such plants. However, the importance of the evaluation of this study during a longer period must be noted. The different responses of the plants might be related to the genetic potential of the genotypes (TAIZ; ZEIGER, 2009).

Therefore, these results are not above those presented by Borges et al. (2008) after they evaluated the absolute growth of the winged-stem passion fruit 70 days after planting (DAP) and, for that, it was evidenced by the treatments that there was a significant increase in the branch length, more

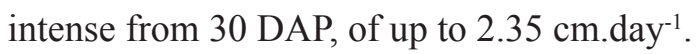

The absolute growth in the stem diameter of the plants in the soil without biofertilizer increased 0.03 $\mathrm{mm}$, reaching the maximum value of $0.05 \mathrm{~mm}$ as a function of the saline content of the irrigation water, until the maximum estimated electrical conductivity of $3.0 \mathrm{dS} \mathrm{m}^{-1}$. In the soil with the biofertilizer, the values referring to the absolute growth in the stem diameter of the neem seedlings did not adjust to any regression model. In spite of the high data dispersion, as a function of the stress caused by the salinity of the irrigation water, the biofertilizer promoted a greater development of the seedlings compared to the soil without the respective input and with the increase in the age of the plants, with a mean value of $0.053 \mathrm{~mm}$. day ${ }^{-1}$.

With these data, it is verified that the organic input promoted an increment in phytomass accumulation of $6 \%$ in the absolute growth rate in terms of stem diameter of the neem plants, if compared to the soil without the respective input.

Once the bovine biofertilizer is applied in the soil, besides contributing to the improvement of the soil attributes (MAVIA et al., 2012) and stimulating its microbiota through the biosynthesis of proline, glycine, nucleic acids and membranes, combined to other complexed elements, there also occurs an increase in the water retention capacity of the soil and in the activity of beneficial microorganisms, increasing the availability of readily available nutrients to the plants, decreasing salinity and soil erosion (AIDYN et al., 2012; SILVA et al., 2012). 
According to Mesquita et al. (2012a), saline stress affects the absorption of water in Citrus species, interfering in the mineral nutrition of plants and, consequently, in the absolute growth of the stem diameter. Mesquita et al. (2012b) subjected seeds of currant tomato (Licopersicon pimpinellifolium) and seedlings of yellow passion fruit (Passiflora edullis Deg.), respectively, to growing salinity levels of the irrigation water, in substrates with and without the bovine biofertilizer, provided to the soil in a liquid form and at a $10 \%$ level in substrate volumes. The authors verified that, regardless of the absence or presence of the organic input, the stem diameter and root and shoot biomass decreased with the increase in water salinity, although with statistically inferior declines in the treatments with the organic input, for both crops.

The behavior of the growth dynamics in absolute terms referring to the plant height (Figure 1) and stem diameter (Figure 2) under the interactions remained similar as a function of the time, what reinforces the idea that the bovine biofertilizer attenuates the aggressive effects of the salts, acting as a soil conditioner (AYDIN et al., 2012). In this perspective, the use of biofertilizer in a non-saline soil in the cultivation of cowpea (SILVA et al., 2012) exercised positive effects in the physical and fertility improvement when applied directly on the soil. This behavior is in accordance with Mavia et al. (2012) and Silva et al. (2012) when evaluating the bovine biofertilizer as a promising organic material for chemical and biological improvements in the soil, also contributing for the aggregation, water retention, and aeration of the soil.

With regard to the decline in the stem diameter, Munns and Tester (2008) report that the inhibition in the growth of the root and shoot systems under saline conditions might be attributed to the reduction in photosynthesis. Under salt stress, the number and size of the leaves of glycophyte plants are reduced due to the low availability of water, given the increase of the saline concentration of the solution and the toxicity by the high concentration of salts in the root environment (TAIZ; ZEIGER, 2009). These results were above to those presented by Mesquita et al. (2012b) in yellow passion fruit seedlings in a non-saline Regolithic Neosol under biofertilizer and with growing levels of salts in the irrigation water, reaching a maximum value of $0.025 \mathrm{~mm}$ at 60 days after emergence (DAE).

Figure 2. Absolute growth (CA) in the stem diameter (SD) of neem seedlings as a function of the content of salts present in the irrigation water in the soil without (---) and with (-) bovine biofertilizer at 180 days after the emergence of the plantlets (DAE). CCA/UFPB, Areia-2016.

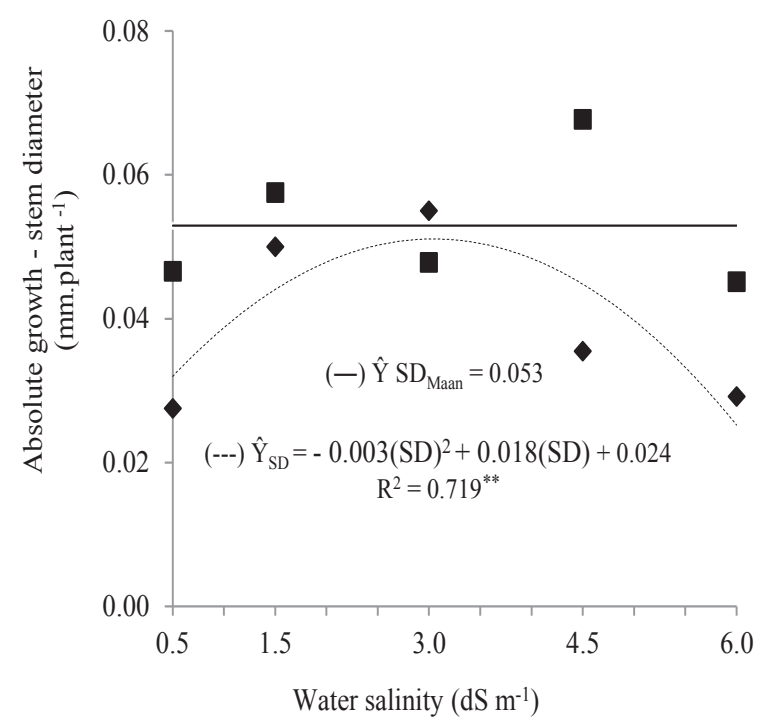


Regardless of the evaluation time, the growth of the seedlings underwent variation due to the water salinity $\mathrm{x}$ biofertilizer interaction, and expresses superiority in the treatments with the biofertilizer, according to the regression analysis $\left(\mathrm{R}^{2}=90.23 \%\right)$. In spite of the high data dispersion as a function of the stress caused by the growing salinity of the irrigation water from 0.5 up to $6.0 \mathrm{dS} \mathrm{m}^{-1}$, the biofertilizer promoted a greater root development compared to the soil without the respective input from 0.081 to 0.057 g.day $^{-1}$ (Figure 3).
In spite of the high data dispersion as a function of the stress caused by the growing salinity of the irrigation water, the neem seedlings reduced their leaf area index from 1.01 to 0.453 in the water electrical conductivity from 0.5 to 3.95 , considering that, from this point, the leaf area index increased proportionally the shoot dry matter production in the period from 120 to 180 DAE, obtaining with that its highest value (0.492) in the soil without the organic compound, in both situations (Figure 3 ).

Figure 3. Leaf area index (IAF) of seedlings of Azadirachta indica under supplemental irrigation with saline water in the soil without (---) and with (-) bovine biofertilizer at 180 days after the emergence of the plantlets (DAE). CCA/ UFPB, Areia-2016.

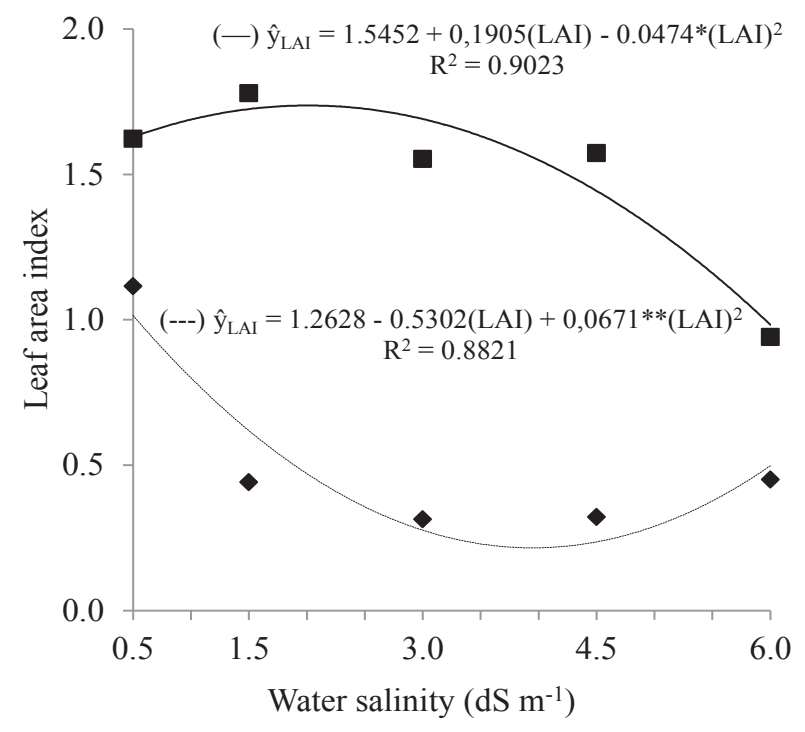

Comparatively, in the plants treated with the common biofertilizer, the decrease in the leaf area index was inversely proportional to the increase in the salinity of the irrigation water, oscillating from 1.62 to 0.98 , that is, in the seedlings without the organic input. Such behavior corresponds to the lowest and highest electrical conductivity of the irrigation water $\left(0.5\right.$ and $\left.6.0 \mathrm{dS} \mathrm{m} \mathrm{m}^{-1}\right)$, verifying that the lack of this fermenting organic compound entailed a decrease of $65.30 \%$ in the leaf area index of the plants.
This decrease might have occurred due to the rise in the osmotic potential of the soil solution. This confirmation is in accordance with Farias et al. (2003) when evaluating the growth and development of melon plants under different salinity levels. These authors verified that the lowest leaf area index of the melon plants for the highest salinity levels reflects the effect of the osmotic potential of the soil solution, inhibiting the absorption of water by the plant. 
Still based on Figure 3, these results in the soil without the input and with waters of growing salinity are compatible with Mesquita et al. (2019) and Santos et al. (2012) after they verified, in the cultivation of the yellow passion fruit (Passiflora edullis Deg.) and in Fabaceae (Crotálaria Juncea), that the increase in the saline content of the irrigation water markedly reduced the Farias et al. (2003yield in phytomass accumulation at considerable salinity levels. However, these data contrast with those presented by) when observing, in melon cultivation, testing different irrigation depths and water salinity levels, satisfactory increases of up to $55.56 \%$ in the absolute growth rate of the root phytomass.
There was an expressive superiority in the neem seedlings obtained in the soil with the bovine biofertilizer compared to the treatments without the input. It is observed that the absolute growth in the root dry matter was drastically reduced with the increase in the salinity of the irrigation water in the soil without the organic input, reaching with that a maximum value of 0.059 g.day ${ }^{-1}$ in the limit salinity of $2.74 \mathrm{dS} \mathrm{m}^{-1}$. This decrease caused the inhibition of $138.87 \%$ in the root phytomass of the irrigated plants with an increase in the saline content of the irrigation water from $2.74 \mathrm{dS} \mathrm{m}^{-1}$ up to $6.0 \mathrm{dS} \mathrm{m}^{-1}$, according to Figure 4.

Figure 4. Absolute growth (CA) of the root dry biomass (RDM) of neem seedlings irrigated with waters of growing salinity in the soil without (---) and with (-) bovine biofertilizer at 180 days after the emergence of the plantlets (DAE). CCA/UFPB, Areia-2016.

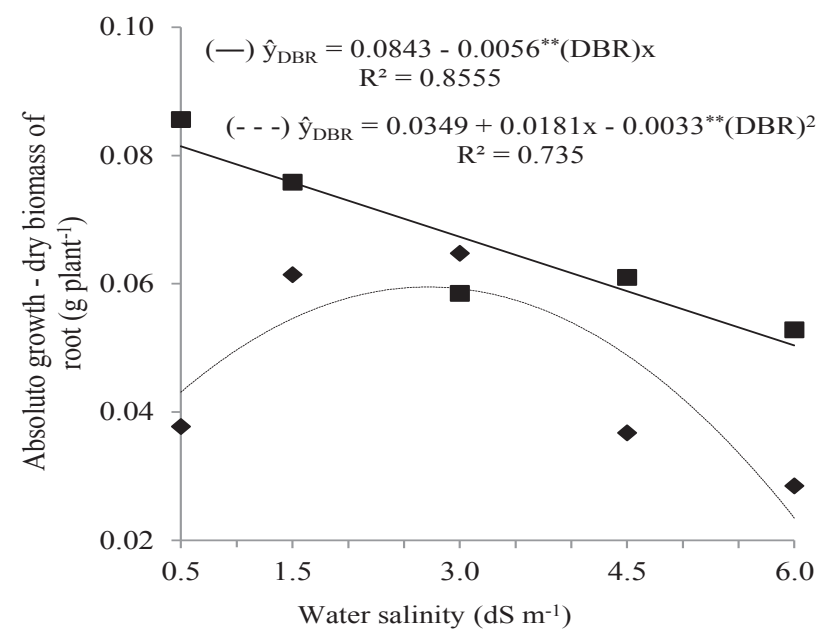

The greater root expansion of the plants in the soil with the biofertilizer is, in general, a response of the better physical condition provided to the substrate by the humic substances contained in the organic input (AIDYN et al., 2012), as well as to the higher accumulation of organic solutes such as soluble carbohydrates and other substances, such as proline, in the plants, raising their capacity for osmotic adjustment (MAVIA et al., 2012).
The increase in the water salinity levels drastically reduced the absolute growth of the shoot dry matter during the formation process of the seedlings in the two periods. There was a superiority for the treatments that received the organic input provided two days before sowing in the two evaluated periods (Figure 5). 
Figure 5. Absolute growth (CA) of the shoot dry matter (MSPA) of Indian neem under supplemental irrigation with saline waters in the soil without (---) and with (-) bovine biofertilizer, in period (A) and in the period (B), referent in the period from 60 to 120 (A) and from 120 to 180 (B) days after the emergence of the plantlets (DAE). CCA/UFPB, Areia-2016.

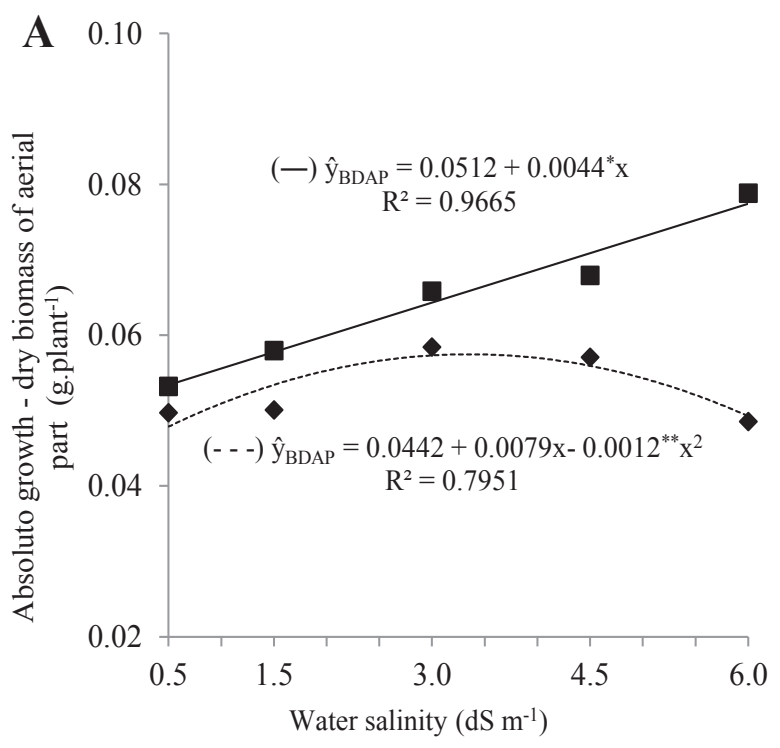

Based on Figure 5, when comparing the values of absolute growth of the shoot dry matter referring to the neem seedlings in the soil without and with the common biofertilizer, in the first period, from 60 to 120 days (A), a variation from 0.057 to 0.078 g.day ${ }^{-1}$ was verified in its dynamic growth, referring to the estimated salinity of 3.29 and $6.0 \mathrm{dS} \mathrm{m} \mathrm{m}^{-1}$, respectively. In the second period, from 120 to 180 days (B), an expressive superiority can be noted in the absolute growth of the neem seedlings until a limit salinity of $3.68 \mathrm{dS} \mathrm{m}^{-1}$, that is, the seedlings reached their maximum growth of 0.152 g.day $^{-1}$ in the soil with the organic input. However, from this point, there was a drastic inhibition of the seedlings caused by the excess of salts present in the root system, decreasing the production of photoassimilates due to the increase of the osmotic

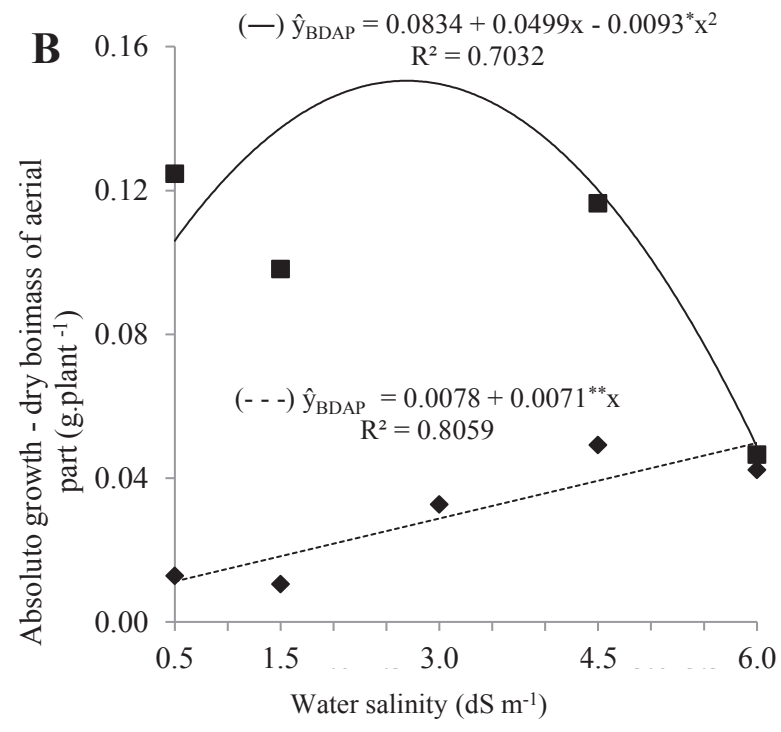

potential in the cell tissues, as well in the osmotic adjustment of the plants.

These results are promising if compared with the data compiled by Dantas et al. (2009) and Mesquita et al. (2012b), when studying the absolute and relative growth in seedlings of Poincianella pyramidalis and yellow passion fruit with the application of organic matter, occurring a significant interaction for the evaluated factors, allowing a lower growth of the seedlings at 60 DAE.

As verified for the absolute growth of the root and shoot dry matter (stem + leaves), the total dry matter of the seedlings of Azadirachta indica, without interference of the time factor, was negatively affected by the increase in the salinity of the irrigation water. However, with lower inhibition in the soil with bovine biofertilizer (Figure 6). 
Figure 6. Absolute growth (CA) of the total dry matter (MST) of neem seedlings under supplemental irrigation with saline waters in a soil without (---) and with (-) bovine biofertilizer at 180 days after emergence of the plantlets (DAE). CCA/UFPB, Areia-2016.

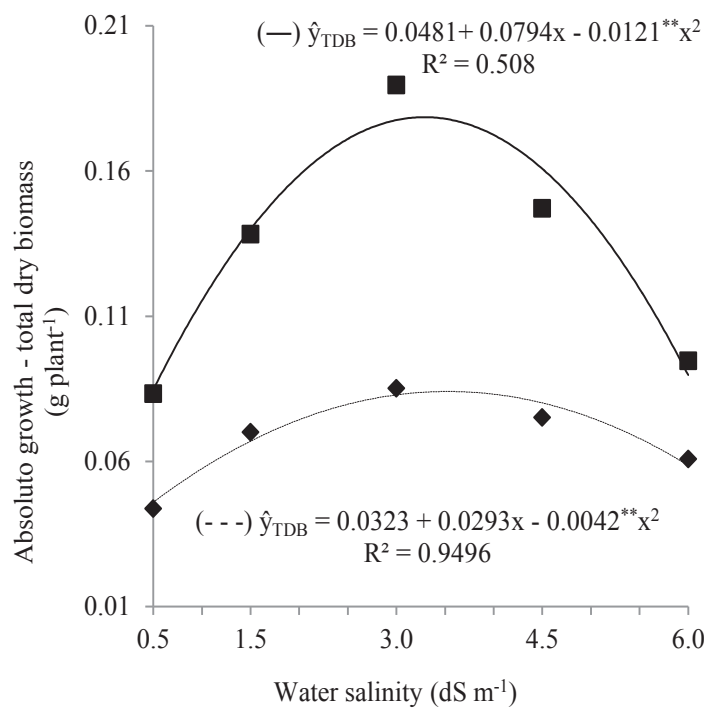

In spite of the expressive superiority at the end of the research, the absolute growth of the shoot + root part of the neem seedlings was drastically reduced with the increase in the salinity of the water, with extreme values of 0.083 and 0.178 g.day $^{-1}$, corresponding to the maximum estimated electrical conductivity of 3.48 and $3.28 \mathrm{dS} \mathrm{m} \mathrm{m}^{-1}$ in the soil without and with common biofertilizer, respectively (Figure 6).

These data challenge those presented by Mesquita et al. (2012b), when they verified, for the cultivation of the yellow passion fruit, the highest absolute growth value of 0.172 g.day $^{-1}$ under growing salinity and with the organic input. The same trend was found by Costa et al. (2010) when studying the biomass production in yellow passion fruit seedlings under different environments, substrates, and types of containers with organic matter, and concluded that the environments closed with polyethylene bags promoted a greater development of the yellow passion fruit seedlings.

\section{Conclusion}

The absolute growth of the seedlings in height, stem diameter, root, shoot, and total dry matter of the neem plants varied with the increase in the salinity of the irrigation water, although with lower intensity in the soil with the biofertilizer.

The superiority of all studied variables in the three periods indicates the positive action of the biofertilizer in the reduction of the deleterious effects of the salts present in the irrigation water to the neem plants.

\section{References}

ALVARES, C. A.; STAPE, J. L.; SENTELHAS, P. C.; GONÇALVES, J. L. M.; SPAROVEK, G. Koppen's climate classification map for Brazil. Meteorologische Zeitschrift, Stuttgart, v. 22, n. 6, p. 711-728, 2013. DOI: 10.1127/0941-2948/2013/0507

AYDIN, A.; KANT, C.; TURAN, M. Humic acid application alleviate salinity stress of bean (Phaseolus vulgaris L.) plants decreasing membrane leakage. African Journal of Agricultural Research, Lagos, v. 7, n. 7, p. 1073-1086, 2012. DOI: 10.5897/AJAR10.274 
BANZATTO, D. A.; KRONKA, S. N. Experimentação agrícola. 4. ed. Jaboticabal: UNESP, 2008. 247 p.

BORGES, D. I.; COSTA, A. C.; HAFLE, O. M.; SANTOS, V. A. dos; CURI, P. N.; PENONI, E. S. Crescimento vegetativo de maracujazeiro-doce nas condições edafoclimáticas de Lavras. In: CONGRESSO BRASILEIRO DE FRUTICULTURA, 20., 2008, Natal. Anais... Natal, MG: Cedagro, 2008. p. 1-6.

COSTA, E.; LEAL, P. A. M.; SANTOS, L. C. R.; VIEIRA, C. R. Ambientes de cultivo, recipientes e substratos na produção de biomassa foliar e radicular em mudas de maracujazeiro amarelo em Aquidauana-MS. Ciência Agrotécnica, Lavras, v. 34, n. 2, p. 461-467, 2010. DOI: 10.1590/S1413-70542010000200027

DANTAS, B. F.; LOPES, A. P.; SILVA, F. F. S.; LÚCIO, A. A.; BATISTA, P. F.; PIRES, M. M. M. L.; ARAGÃO, C. A. Taxas de crescimento de mudas de catingueira submetidas a diferentes substratos e sombreamentos. Revista Árvore, Viçosa, MG, v. 33, n. 3, p. 413-423, 2009. DOI: $10.1590 / \mathrm{S} 0100-67622009000300003$

DEBASHRI, M.; TAMAL, M. A review on efficacy of azadirachta indica a. juss based biopesticides: an indian perspective. Research Journal of Recent Sciences, Hyderabad, v. 1, n. 3, p. 94-99, 2012. Available at: https:// www.researchgate.net/publication/233528571_A_ Review_on_efficacy_of_Azadirachta_indica_ A_Juss based_biopesticides_An_Indian_perspective. Accessed at: 24 sept. 2019.

DUTRA, T. R.; MASSAD, M. D.; SANTANA, R. C. Parâmetros fisiológicos de mudas de copaíba sob diferentes substratos e condições de sombreamento. Ciência Rural, Santa Maria, v. 42, n. 7, p. 1212-1218, 2012. DOI: $10.1590 / \mathrm{S} 0103-84782012005000048$

EMPRESA BRASILEIRA DE PESQUISA AGROPECUÁRIA - EMBRAPA. Centro Nacional de Pesquisa de Solos. Manual de métodos de análise do solo. 3. ed. Rio de Janeiro: EMBRAPA, 2017. 573 p. (EMBRAPA, CNPS. Documentos, 1).

EMPRESA BRASILEIRA DE PESQUISA AGROPECUÁRIA - EMBRAPA. Centro Nacional de Pesquisa de Solos. Sistema brasileiro de classificação de solos. 3. ed. Brasília: EMBRAPA Solos, 2013. 353 p.

FARIAS, C. H.; SOBRINHO, J. E.; MEDEIROS, J. F.; COSTA, M. C.; NASCIMENTO, I. B.; SILVA, M. C. C. Crescimento e desenvolvimento da cultura do melão sob diferentes lâminas de irrigação e salinidade da água. Revista Brasileira de Engenharia Agrícola e Ambiental, Campina Grande, v. 7, n. 3, p. 445-450, 2003. DOI: $10.1590 /$ S1415-43662003000300006
FERREIRA, D. F. Sisvar: a computer statistical analysis system. Ciência e Agrotecnologia, Lavras, v. 35, n. 6, p. 1039-1042, 2011. DOI: 10.1590/S141370542011000600001

FONTES, P. C. R.; DIAS, E. N.; SILVA, J. H. Dinâmica do crescimento, distribuição de matéria seca e produção de pimentão em ambiente protegido. Horticultura Brasileira, Brasília, v. 23, n. 1, p. 94-99, 2005. Disponível em: http://www.scielo.br/pdf/hb/v23n1/a20v23n1.pdf. Acesso em: 24 sept. 2019.

FREIRE, L. O.; CAVALCANTE, L. F.; REBEQUI, A. M.; DIAS, T. J.; NUNES, J. C.; CAVALCANTE, I. H. L. Atributos qualitativos do maracujá amarelo produzido com água salina, biofertilizante e cobertura morta no solo. Revista Brasileira de Ciências Agrárias, Recife, v. 5, n. 1, p. 102-110, 2010. DOI: 10.5039/agraria.v5i1a674

MATSI, T. H.; LITHOURGIDIS, A. S.; BARBAYIANNIS, N. Effect fliquid cattle manure on soil chemical properties and corn growth in Northern Greece. Experimental Agriculture, Cambridge, v. 51, n. 3, p. 435-450, 2015. DOI: $10.1017 / \mathrm{S} 001447971400040$

MAVIA, M. S.; MARSCHNERA, P.; CHITTLEBOROUGHC, D. J.; COXC, J. W.; SANDERMANE, J. Salinidade e sodicidade afetam a respiração do solo e da dinâmica da matéria orgânica dissolvida diferencialmente em solos de diferentes texturas. Soil Biology and Biochemistry, Elmsford, v. 45, n. 1, p. 8-13, 2012. Disponível em: https://magistraonline. ufrb.edu.br/index.php/magistra/article/view/480. Acesso em: 24 sept. 2019.

MEDEIROS, S. A. S.; CAVALCANTE, L. F.; BEZERRA, M. A. F.; NASCIMENTO, J. A. M.; BEZERRA, F. T. C.; PRAZERES, S. S. Água salina e biofertilizante de esterco bovino na formação e qualidade de mudas de maracujazeiro amarelo. Irriga, Botucatu, v. 21, n. 4, p. 779-795, 2016. Disponível em: http:// revistas.fca.unesp. br/index.php/irriga/issue/view/90. Acesso em: 24 sept. 2019.

MELLEK, J. E.; DIECKOW, J.; SILVA, V. L.; FAVARETTO, N.; PAULETTI, V.; VEZZANI, F. M.; SOUZA, J. L. M. Dairy liquid manure and no-tillage: physical and hydraulic properties and carbon stocks in a Cambisol of Southern Brazil. Soil \& Tillage Research, Shanghai, v. 110, n. 1, p. 69-76, 2010. Disponível em: http://www.moretti.agrarias.ufpr.br/publicacoes/ tc_2010_soil_tillage_research_1.pdf. Acesso em: 24 sept. 2019.

MESQUITA, F. O.; CAVALCANTE, L. F.; OLIVEIRA FILHO, F. X.; RODRIGUES, R. M.; CAMPOS, V. B.; SOUZA, J. K. C. Neem relative growth under 
supplemental irrigation with saline waters and biofertilizer. Comunicata Scientiae, Bom Jesus, v. 10, n. 1, p. 45-53, 2019. DOI: 10.14295/cs.v10i1.2936

MESQUITA, F. O.; CAVALCANTE, L. F.; PEREIRA, W. E.; REBEQUI, A. M.; LIMA NETO, A. J.; NUNES, J. C. Produção de mudas de maracujazeiro amarelo submetidas à salinidade em solo com biofertilizante bovino.. Revista Ciencia del Suelo, Buenos Aires, v. 30, n. 1, p. 31-41, 2012a. Disponível em: http://www.scielo.org.ar/scielo. php? pid $=$ S 1850-20672012000100004\&script $=$ sci abstract. Acesso em: 24 sept. 2019.

MESQUITA, F. O.; NUNES, J. C.; LIMA NETO, A. J.; LUNA SOUTO, A. G.; BATISTA, R. O.; CAVALCANTE, L. F. Formação de mudas de nim sob salinidade da água, biofertilizante e drenagem do solo. Irriga, Botucatu, v. 20, n. 2, p. 193-203, 2015. DOI: 10.15809/irriga.2015v20n2p193

MESQUITA, F. O.; REBEQUI, A. M.; CAVALCANTE, L. F.; LUNA SOUTO, A. G. L. Crescimento absoluto e relativo de mudas de maracujazeiro sob biofertilizante e águas salinas.r Revista de Ciências Agrárias, Lisboa, v. 30, n. 1, p. 222-239, 2012b. Disponível em: http:/www. scielo.mec.pt/pdf/rca/v35n1/ v35n1a22.pdf. Acesso em: 24 sept. 2019.

MUNNS, R.; TESTER, M. Mechanisms of salinity tolerance. Annual Review of Plant Biology, Canberra, v. 59, n. 1, p. 651-681, 2008. DOI: 10.1146/annurev. arplant.59.032607.092911

NASCIMENTO, I. B.; MEDEIROS, J. F.; ALVES, S. S. V.; LIMA, C. B. L.; SILVA, J. L. A. Desenvolvimento inicial da cultura do pimentão influenciado pela salinidade da água de irrigação em dois tipos de solos. Agropecuária Científica no Semiárido, Patos, v. 11, n. 1, p. 37-43, 2015. DOI: 10.30969/acsa.v11i1.594

OLIVEIRA, F. I. F.; SOUTO, A. G. L.; CAVALCANTE, L. F.; MEDEIROS, W. J. F.; BEZERRA, F. T. C.; BEZERRA, M. A. F. Quality of jackfruit seedlings under saline water stress and nitrogen fertilisation. Semina:
Ciências Agrárias, Londrina, v. 38, n. 4, p. 2337-2350, 2017. DOI: 10.5433/1679-0359.2017v38n4Sup11p2337

OLIVEIRA, F. I. F.; SOUTO, A. G. L.; CAVALCANTE, L. F.; MEDEIROS, W. J. F.; MEDEIROS, S. A. S.; OLIVEIRA, F. F. Biomass and chloroplast pigments in jackfruit seedlings under saline stress and nitrogen fertilization. Revista Caatinga, Mossoró, v. 31, n. 3, p. 622-631, 2018. DOI: 10.1590/1983-21252018v31n310rc

PEDROTTI, A.; CHAGAS, R. M.; RAMOS, V. C.; PRATA, A. P. N.; LUCAS, A. A. T.; SANTOS, P. B. Causas e consequências do processo de salinização dos solos. Revista Eletrônica em Gestão, Educação e Tecnologia Ambiental, Santa Maria, v. 19, n. 2, p. 13081324, 2015. DOI: 105902/2236117016544

RIBEIRO, H.; JAIME, P. C.; VENTURA, D. Alimentação e sustentabilidade. Estudos Avançados, São Paulo, v. 31, n. 89, p. 185-198, 2017. DOI: 10.1590/ s0103-40142017.31890016

RICHARDS, L. A. Diagnosis and improvement of saline and alkaline soils. Washington: United States Salinity Laboratory Staff, 1954. 160 p. (Agriculture, 60).

SANTOS, C. S.; CARNEIRO, P. T.; SANTOS, V. R.; SANTOS, M. A. L.; SANTOS, R. A.; SANTOS JÚNIOR, J. M. Taxas de crescimento de fabáceas irrigadas com águas salinas. In: WOKSHOP INTERNACIONAL DE INOVAÇÕES TECNOLÓGICAS NA IRRIGAÇÃO, 4., 2012, Fortaleza. Anais... Fortaleza: INOVAGRI, 2012. CD-ROM.

SILVA, F. L. B.; LACERDA, C. F.; NEVES, A. L. R.; SOUSA, C. H. C.; FERREIRA, F. J.; SILVA JÚNIOR, R. J. C. Trocas gasosas em plantas de feijão-de-corda à aplicação foliar de biofertilizante, sob condições de salinidade. In: WOKSHOP INTERNACIONAL DE INOVAÇÕES TECNOLÓGICAS NA IRRIGAÇÃO, 4., 2012, Fortaleza. Anais... Fortaleza: INOVAGRI, 2012. CD-ROM.

TAIZ, L.; ZEIGER, E. Fisiologia vegetal. 4. ed. Porto Alegre: Artmed, 2009. 719 p. 
